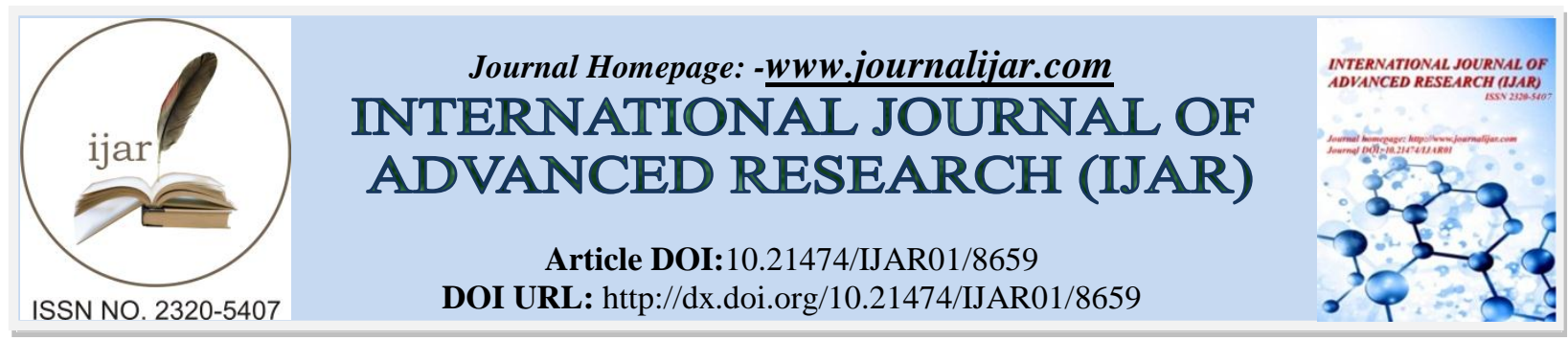

RESEARCH ARTICLE

\title{
A REVIEW ON EFFECT OF FLUORIDE CONCENTRATION IN DRINKING WATER.
}

Ugale B. J. ${ }^{1}$, Jawale C. $A^{2}$, Rathod G.T ${ }^{3}$ and Suryawanshi M. $T^{1}$.

1. Shrikrishna Mahavidyalaya Gunjoti, Ta Omerga Dist. Osmanabad (M.S).

2. Shri Madhavrao Patil Mahavidyalaya Murum Ta Omerga Dist. Osmanabad (M.S).

3. Jawahar Arts, Science and Commerce College, Anadur Ta. Tuljapur, Dist. Osmanabad (M.S.).

\section{Manuscript Info}

Manuscript History

Received: 09 January 2019

Final Accepted: 11 February 2019

Published: March 2019

Key words:-

Water, Fluoride, Concentration,

Fluorosis, Dental fluorosis, Causes,

Toxicity.

\section{Abstract}

The aim of our topic is to Review on Effect of Fluoride Concentration in Drinking Water to review the literature about fluoride toxicity and to know knowledge about fluoride effect. The deep ground water from drilled wells is naturally occurring high fluorides content whereas surface water and water from traditional shallow dug wells have lower fluoride. Consumption of higher regular dose of fluoride contaminated water and food causes fluorosis. Fluorosis has attained an alarming dimension all over world including India. Fluoride adverse effects depend on total fluoride dosage from all sources.

High intake results in the molting of teeth enamel, symptoms commonly evident in children below Eight years. Some specific effects are Dental fluorosis, skeletal fluorosis, Non-skeletal/Soft tissue fluorosis, etc. Products to have high fluoride content should be avoided. It is also Control by in daily diet adequate amount of calcium, vitamins $\mathrm{A}, \mathrm{C}$ and $\mathrm{D}$ should be regularly included.

Copy Right, IJAR, 2019,. All rights reserved.

\section{Introduction:-}

Rapid Industrialization and geochemical dissolution of Fluoride bearing minerals are increasing fluoride concentration in atmosphere as well as in water resources. The Fluoride level in water in India ranges from 2-29 ppm (Pandey S.N., Misra S.P.2011). The World Health Organization recommends a guideline maximum fluoride value of $1.5 \mathrm{mg} / \mathrm{L}$ as a level at which fluorosis should be minimal (Fawell J, et.al 2006).

Traces of fluorides are present in many waters; higher concentrations are often associated with underground sources. In sea water, a total fluoride concentration of 1.2 to $1.5 \mathrm{mg} /$ liter has been reported (Slooff et. al., 1988). In areas rich in fluoride-containing minerals, well water may contain up to about $10 \mathrm{mg} /$ liter of fluoride. The highest natural level reported is $2800 \mathrm{mg} /$ liter. Fluorides may also enter a river as a result of industrial discharges (Slooff et.al. 1988, WHO 2004).

Fluorine is present in the lithosphere, atmosphere, hydrosphere and biosphere. A large amount of fluorine can be found in rocks of volcanic origin. It enters the environment through volcanic eruptions, rock dissolution and numerous human activities (coal burning, ore processing, production and use of fertilizers, and industrial plants). Fluoride is found in all natural waters. Higher concentrations of fluoride in water can be present near hot springs of volcanic origin ( Domen Kanduti, et. Al 2016). 


\section{Methods and Sources:-}

Data we used in our review were systematically searched from research articles published and collected from official web pages, reference book and documents published from different international institutions.

\section{Fluorosis:}

Fluorosis, a public health problem is caused by excess intake of fluoride through drinking water/food products/industrial emission over a long period. It results in major health disorders like dental, skeletal and nonskeletal fluorosis. The health of an individual and the community, which in turn has adverse effects on growth, development and economy of the country (Water Quality and Fluorosis in India 2016)

Fluoride's effects depend on the total daily intake of fluoride from all sources. Drinking water is typically the largest source of fluoride (Fawell J 2006). In many industrialized countries swallowed toothpaste is the main source of fluoride exposure in unfluoridated communities (Sheiham A. 2001). Other sources include dental products other than toothpaste, air pollution from fluoride-containing coal or from phosphate fertilizers, and tea leaves, particularly the tea bricks favored in parts of China. High fluoride levels have been found in other foods, including barley, cassava, corn, rice, taro, yams, and fish protein concentrate (www.water fluoridation ). General symptoms of fluorosis due to high intake of fluoride are tabulated in Table: (Pandey S.N., Misra S.P.2011)

\begin{tabular}{|l|l|l|l|}
\hline Sr.No. & $\begin{array}{l}\text { Concentration of } \\
\text { Fluoride }\end{array}$ & Source & Effects \\
\hline 1 & $1 \mathrm{ppm}$ & Water & Reduction of dental caries \\
\hline 2 & $1-2 \mathrm{ppm}$ & Water & Dental fluorosis or mottled enamel \\
\hline 3 & $8 \mathrm{ppm}$ & Water & $10 \%$ Osteosclerosis \\
\hline 4 & $20-80 \mathrm{mg} /$ day & Water and food & Crippling Skeletal fluorosis \\
\hline 5 & $50 \mathrm{ppm}$ & Water and food & Thyroid changes \\
\hline 6 & $100 \mathrm{ppm}$ & Water and food & Growth retardation \\
\hline 7 & $125 \mathrm{ppm}$ & Water and food & Kidney damages \\
\hline 8 & $2.5-5.0 \mathrm{~g} / \mathrm{l}$ & Acute dose (air, water and food) & Death \\
\hline
\end{tabular}

Table:-Fluoride Concentration, Source and symptoms.

High exposure to fluoride causes immediate abdominal pain, nausea, vomiting, muscle spasm, etc. a symptoms commonly evident in children below eight years. Some specific effects are Dental fluorosis, skeletal fluorosis, Nonskeletal/Soft tissue fluorosis, Low hemoglobin levels etc.

\section{Dental fluorosis:}

In addition to fluoride in drinking water, people also can ingest fluoride in toothpaste, mouth rinse, and dietary fluoride supplements or in beverages and foods prepared with fluoridated water. (Mary Tiemann 2011). During this period before teeth erupt that dental tissues are very sensitive to fluoride (typically during a child's first eight years). Mild dental fluorosis is characterized by opaque white or stained patches in the dental enamel. More severe fluorosis is characterized by pitting of tooth enamel. Teeth become rough opaque and chalky white (mottled) may have white, yellow, brown or black spots or streaks on the enamel surface.

Dental fluorosis is associated with other conditions, such as vitamins A and D deficiency or a low protein-energy diet). Ingestion of fluoride after six years of age will not cause dental fluorosis.

\section{Skeletal fluorosis:}

Prolonged intake of water containing more than $8 \mathrm{mg} / \mathrm{liter}$ leads to skeletal fluorosis. Bow legs and knock knees (outward bending) are characteristic feature of skeletal fluorosis. Maximum effects are detected in the neck, spine, knees pelvic and shoulder joints. Crippling deformity is associated with rigidity of joints, increased convexity in curvature of the spine, lateral curvature of vertebral column, deformity of knee joints and paralysis of lower parts of body including legs. 


\title{
Non-skeletal/Soft Tissue Fluorosis:
}

Excess intake of fluoride can damage soft tissues, organs and symptoms called non-skeletal or visceral fluorosis. Muscle, liver, kidney, blood, cardiovascular and reproductive systems are affected. It affects men, women and children of all age groups.

\section{Low hemoglobin levels:}

Cells of RBC become amoeboid with short life span. The shape of erythrocytes is changed. Such RBCs are called echinocytes, and found in circulation. The echinocytes undergo phagocytosis (eaten-up by macrophages) and are eliminated from circulation. This would lead to low hemoglobin levels in patients chronically ill due to fluoride toxicity.

\author{
Allergic Manifestations: \\ In fluoride endemic areas, painful pinkish or bluish red skin rashes with round spots have been reported. Such spots \\ fade away after a week or so.
}

Urinary tract manifestations:

Reduction in the volume of urine and itching in urinary tract are reported in fluoride toxicity. It occurs due to adverse effect of fluoride on brain areas that control this system.

\section{Muscular manifestations:}

Muscle weakness \& stiffness, pain in the muscle and loss of muscle power, inability to carry out normal routine activities.

\section{Other risk factors:}

1. Several of the ready to serve foods, beverages, snacks have high content of black rock salt (CaF2) or 'kala namak' (which has $157 \mathrm{ppm}$ fluoride) and red rock salts.

2. Tobacco or supari when they are chewed.

3. Fluoride-rich foods such as tea, ocean fish, gelatin, skin of chicken, fluoridated salt, food contaminated with post-harvest fumigants (e.g. sulfuryl fluoride) and pesticides (e.g. sodium aluminum fluoride, Na3AlF6, which may be used on grapes)..

4. Fluoride from any other environmental sources, including cigarette smoke and industrial pollution,

5. Diets rich in fat have been reported to increase deposition of fluoride in bones.

\section{Prevention:}

Prevention is always better than cure. Some important measures for prevention are:

1. Use water having no fluoride. Safe and adequate range for adults is $1.5-4.0 \mathrm{mg} / \mathrm{day}$ and it is less for children.

2. Products proven to have high fluoride content should be avoided, such as fluoride containing tooth pastes, mouth rinses or any other products.

3. However, the disease is easily preventable if diagnosed early and steps are taken to prevent intake of excess fluoride through provision of safe drinking water, promote nutrition and avoid foods with high fluoride content.

\section{Control measures:}

1. Pain in back bone, neck, hip and joints should not be dismissed

2. Adequate amount of calcium, vitamins $\mathrm{A}, \mathrm{C}$ and $\mathrm{D}$ should be regularly included in daily.

3. The simple control includes conservation of surface water, rainwater, consumption of low-fluoride groundwater and by putting in place better drinking water standards. Other control is defluoridation of water.

\section{Conclusion:-}

Fluoride is found in all natural waters. Exposure can occur through dietary intake, respiration and fluoride supplements. Fluoride's adverse effects depend on total fluoride dosage from all sources. High intake results in the molting of teeth enamel, symptoms commonly evident in children below Eight years. Some specific effects are Dental fluorosis, skeletal fluorosis, and Non skeletal/Soft tissue fluorosis. Products proven to have high fluoride content should be avoided, It is Control by in daily diet Adequate amount of calcium, vitamins A, C and D should be regularly included. 


\section{References:-}

1. Fawell J, Bailey K, Chilton J, Dahi E, Fewtrell L, Magara Y(2006): Fluoride in Drinking-water [PDF]. World Health Organization; 2006.ISBN 92-4-156319-2.Guidelines and standards. p. 37-9.

2. Mary Tiemann(2011): Fluoride in Drinking Water: A review of Fluoridation and regulation Issue January 3, 2011.

3. Pandey S.N., Misra S.P. (2011): Environment and Ecology Ane Books Pvt.Ltd. New Delhi. Water Born and Water Induced Disease and Fluoride Problem P.279-282.

4. Sheiham A (2001): Dietary effects on dental diseases. Public Health Nutr. 2001; 4(2B):569-91.

5. Slooff W et al., eds. (1988): Basis document fluoriden. Bilthoven, Netherlands, National Institute of Public Health and Environmental Protection (Report No. 758474005).

6. World Health Organization (2004): Fluoride Drinking Water, Background document of development of WHO Guideline for Drinking-water Quality.

7. www.water fluoridation from Wikipedia, the free encyclopedia. 